DOI https://doi.org/10.30525/978-9934-26-074-2-16

\title{
ЩОДО ЮРИДИЧНОЇ ПРИРОДИ РОЗРАХУНКІВ БАНКІВСЬКИМИ КАРТАМИ
}

\author{
Кривенко Ю. В. \\ кандидат юридичних наук, дочент, \\ дочент кафедри ичивільного права \\ Національного університету «Одеська юридична академія» \\ Адаховська Н. С. \\ кандидат юридичних наук, дочент, \\ дочент кафедри циивільного права \\ Наиіонального університету «Одеська юридична академія» \\ Спасова К. I. \\ асистент кафедри циивільного права \\ Національного університету «Одеська юридична академія» \\ м. Одеса, Україна
}

Однією 3 головних рис сучасного цивільного обороту є прискорення його темпів. У сфері розрахунків дана тенденція обумовлює перехід від розрахунків, заснованих на паперових носіях, до розрахунків за допомогою документів в електронній формі.

Видом таких розрахунків $є$ розрахунки з використанням банківських платіжних карт, які вже набули великого поширення в закордонних країнах у зв'язку з вигодою для банків, їх клієнтів та організацій торгівлі.

Разом 3 тим правова база даних операцій ще належним чином не сформована й не охоплює всього комплексу питань, пов'язаних 3 їх використанням.

Відповідно до цивільного законодавства (п. 1 ст. 1066 ЦК України) предмет договору банківського рахунку обмежується операціями, що здійснюються на рахунку - приймання і зарахування грошових коштів, перерахування та видача відповідних сум з рахунку, проведення інших операцій за рахунком [1]. Порядок виконання зобов'язань, виражених в розрахункових документах, залишається за межами предмета договору банківського рахунку.

Чинне законодавство не містить поняття безготівкових розрахунків або їх форм. Доктрина права визначає форми безготівкових розрахунків як «врегульовані законодавством умови виконання через банк грошових зобов'язань, що відрізняються порядком зарахування грошових коштів 
на рахунок кредитора, видом розрахункового документа i порядку документообігу». [2].

Банківську карту можна також визначити як засіб доступу до банківського рахунку іiї власника. Згідно з цим визначенням операції, що здійснюються з використанням банківських карт, є предметом договору банківського рахунку.

У ст. 1 Закону України «Про платіжні системи та переказ коштів в Україні» визначено, що «платіжна картка - електронний платіжний засіб у вигляді емітованої в установленому законодавством порядку пластикової чи іншого виду картки, що використовується для ініціювання переказу коштів 3 рахунка платника або 3 відповідного рахунка банку з метою оплати вартості товарів і послуг, перерахування коштів зі своїх рахунків на рахунки інших осіб, отримання коштів у готівковій формі в касах банків через банківські автомати, а також здійснення інших операцій, передбачених відповідним договором». [3].

Банківські пластикові картки дозволяють їх власникам проводити операції, які недоступні або є незручними для інших платіжних засобів, таких, наприклад, як замовлення й оплата товарів за кордоном, бронювання номерів у готелях, бронювання автомобілів.

Комерційні банки випускають пластикові карти, які називаються банківськими.

Значна кількість громадян отримують заробітну плату за допомогою банківської карти - підприємства перераховують ії на карткові рахунки своїх працівників, відкриті в тому чи іншому банку. За даними НБ України, емісія банківських карт зростає безперервно, а кількість власників банківських карт поступово наближається до європейських країн. В останні роки ринок банківських карт розвивається дуже швидкими темпами. На думку експертів провідних міжнародних платіжних систем, український ринок - один 3 найперспективніших. Наприклад, загальна кількість емітованих платіжних карток в Україні станом на 01 жовтня 2020 року становила 73,4 млн шт. Це більше на 7,4\%, якщо порівняти з січнем 2020 року. [4].

Всі банківські карти, які випускає банк для своїх клієнтів, діляться на дебетові та кредитні.

Дебетова карта - це пластикова карта, на яку клієнт або роботодавець вносить (перераховує) грошові кошти для подальшого використання, в тому числі для оплати товарів і послуг. 3 неї можна зняти в банкоматі готівку, але тільки в межах суми, яка знаходиться на рахунку власника картки. На залишок коштів на рахунку клієнта банк нараховує відсотки, але, як правило, ставка відсотка набагато нижче, ніж за депозитними строковими вкладами. За обслуговування картки банк стягує з клієнта комісію. Розмір комісії залежить від того, який тип карти знаходиться у вашому розпорядженні. Найбільші комісії стягуються 3 власників так званих «золотих карт», менші суми списуються 3 рахунків власників звичайних дебетових карт.

70 
По суті, коли ми витрачаємо гроші по дебетовій картці, ми витрачаємо гроші прямо зараз, гроші витрачаються безпосередньо 3 нашого рахунку. Одночасно зі списанням коштів 3 карткового рахунку ми отримуємо SMS-повідомлення про списану суму й наявний залишок коштів на рахунку. Отримання повідомлення про списання коштів 3 карткового рахунку за допомогою SMS - це спеціальна опція, яку можуть отримати власники карт, активувавши цю послугу в тому відділенні банку, де вони оформляли дебетову карту. Наявність такої послуги дозволяє клієнтам контролювати свої витрати.

На відміну від дебетової карти, кредитна карта - це пластикова карта, по якій ми витрачаємо гроші «потім». Це означає, що по цій карті банк відкриває клієнту кредитну лінію, обмежену певним лімітом, тобто сумою, яка не може бути перевищена. На використану суму кредитної лінії банк бере 3 клієнта відсотки за користування кредитом. Відновлювати кредитну лінію банк може в міру погашення клієнтом заборгованості за кредитом. Зараз все частіше банки надають клієнту так званий пільговий період, свого роду канікули, протягом яких банк не бере $з$ клієнта плату за вже витрачені на кредитній карті гроші. Якщо на карті встановлено пільговий період, використання банківських грошей буде безплатним, якщо ми встигнемо погасити свою заборгованість перед банком впродовж пільгового періоду.

Зустрічаються банківські пластикові картки - дебетово-кредитні, які поєднують в собі ознаки дебетової і кредитної карт. Тобто карта $\epsilon$ дебетовою, якщо на рахунку іï власника є грошові кошти. Як тільки клієнт витратить свої кошти, банк його кредитує на необхідну суму (але в межах встановленої кредитної лінії). Відновити кредитну лінію банк може за умови своєчасного погашення клієнтом свого боргу по кредиту. Якщо потенційний власник кредитної карти - клієнт банку-емітента банківських карт, то він може звернутися до банку 3 проханням встановити на нього кредитний ліміт.

Отже, в цей час нагальним завданням для законодавців слід передбачити законодавче закріплення розрахунків 3 використанням банківських карт. Викладені вище питання необхідно розглядати 3 урахуванням ре кодифікації цивільного законодавства. 3 урахуванням питань, які виникають на практиці необхідно передбачити надання адекватного захисту інтересів власників платіжних карт, та передбачити правила, які адаптували б правовий режим договору банківського рахунку до технологічних особливостей операцій з платіжними картами.

Вважаємо, що саме чітке нормативне регулювання даної сфери розрахунків не тільки допоможе захистити законні інтереси всіх учасників правовідносин, що виникають при використанні банківських карт, але і буде сприяти подальшому їх впровадженню в повсякденне життя і розвитку безготівкових розрахунків. Однак оскільки, виходячи 3 викладеного, нині чинний спосіб правового регулювання неповноцінний, має ряд фактичних обмежень i не відтворює національні інтереси, 
очевидний висновок про необхідність вдосконалення спеціального законодавства, що регулює правовідносини у сфері банківських карт або внесення відповідних змін до вже наявного законодавства. Вважаємо, що саме такий варіант може сприяти подальшому розвитку національних платіжних систем, а також дозволить розв'язати наявні проблеми у сфері здійснення безготівкових розрахунків за допомогою банківських карт.

\title{
Література:
}

1. Цивільний кодекс України// Відомості Верховної Ради України (BBP), 2003. №№ 40-44. Ст. 356.

2. Коць О.О., Гоменюк В.В. Сучасний стан і перспективи розвитку ринку платіжних карток в Україні. Економіка і суспільство. Випуск № 15. 2018. C. 671-678. URL:http://economyandsociety.in.ua/journal/ 15_ukr/102.pdf

3. Про платіжні системи та переказ коштів в Україні:Закон України. Електронний ресурс. Режим доступу :https://zakon.rada.gov.ua/laws/show/ 2346-14\#Text

4. Беззаперечні тренди карткового ринку у 2020 році - розрахунки в Інтернеті та безконтактні платежі .Електронний ресурс .Режим доступу : https://bank.gov.ua/ua/news/all/bezzaperechni-trendi-kartkovogo-rinku-u2020-rotsi--rozrahunki-v-interneti-ta-bezkontaktni plateji\#: :text=Загальна\% 20кількість\%20емітованих\%20платіжних\%20карток,порівняти\%203\%20с ічнем\% $\% 20202 \% 20$ року*.

DOI https://doi.org/10.30525/978-9934-26-074-2-17

\section{ЕВОЛЮЦІЯ СТАНОВЛЕННЯ ЗАКОНОДАВСТВА В СФЕРІ ВИКОРИСТАННЯ ІНФОРМАЦЙННИ ТЕХНОЛОГІЙ У ЦИВІЛЬНОМУ ПРОЦЕСІ}

\author{
Маричева О. Д. \\ адвокат, \\ заступник директора юридичного департаменту \\ $T_{3} O B$ «ПЛГ «Micm Груп», \\ аспірант кафедри ичвільно-правових дисциплін \\ Інституту права \\ Львівського державного університету внутрішніх справ \\ м. Львів, Україна
}

Сучасне життя людей, його інформатизація безумовно впливають на всі сфери соціально-економічного, політичного і культурного життя 